\section{Economy in Drugs}

A memorandum on "Economy in the Use of Drugs in War Time" by the Therapeutic Requirements Committee of the Medical Research Council has been issued as an official publication. It is based on the provisional lists circulated last autumn, a summary of which appeared in NATURE (October 12, 1940). These lists have been thoroughly revised and greatly extended. Some five hundred drugs are elassified into three groups : (1) essential or readily available ; (2) essential for certain purposes but in the use of which strict economy should be observed; and (3) not essential. By a recent Defence Regulation, the Ministry of Health was empowered to make Orders authorizing the replacement of scarce drugs by alternatives having substantially the same therapeutic action; it is understood that the Medical Research Council is the body which advises on essential and non-essential medicinal substances, and consequently this memorandum is of no little importance, since it may be taken that it gives at least some indication of the drugs which may be the subject of Orders. In the meantime, medical men are expected to avoid the prescription of drugs in classes 2 and 3 so far as possible. Of more permanent interest is an appendix to the memorandum, consisting of the names of drugs which, in the view of the Medical Research Council, should be produced in the British Empire and should be encouraged.

\section{Post-War Building and Planning}

SомE aspects of the problem of post-War building are discussed in Electrical Industries of February. It seems clear that some limitation of the size of our future towns and cities will have to be seriously contemplated. This, in turn, will inevitably give rise to many indirect problems of a complicated nature. From the point of view of electrical supply, no matter what type of building in our reconstructed areas is finally decided on, the vast potentialities for the extended use of electricity can readily be visualized; especially when we bear in mind that the work of reconstruction will not only be confined to housing, but will also embrace industry and its location. The general plan of reconstruction will probably take into consideration, besides the bombed areas, those slum clearance schemes held in abeyance for the duration of the War. It would be dangerous to encourage the public to expect too much from postWar reconstruction, especially in its early stages, and already a warning has been issued by Lord Reith on this subject. So far as electric supply authorities are concerned, many of the pre-War development schemes which have necessitated, or will necessitate, the laying down of new sub-stations and networks to cater for future requirements may have to be drastically revised. One of the most important points is -that when normal times return and the preliminary surveys are made, the electric supply industries, assisted by such bodies as the Electrical Development Association, the British
Standards Institution and the British Electrical and Allied Industries Research Association, should be in a position to place immediately before the appropriate authority the electrical position in its entirety.

\section{Air Raid Damage to the London Museum}

THE damage sustained by the London Museum has been confined almost entirely to its glass. The major portion of the windows on the south front, the glass in the lantern of the Main Hall and that of the lantern in the Costume Gallery, which was of ground-glass, decorated with allegorical figures, have been destroyed. The matchless gilded ceilings and the painted panels have, however, escaped damage, and even the original chandeliers and candelabra have been in the main uninjured. Before the outbreak of war, most of the collections were removed from the building, only some of the more cumbrous exhibits and models being left in the basement, and a small collection of less important duplicate material being retained for special exhibitions, and for the illustrations of a course of lectures, which was given in the early part of last year. The collections are thus intact, even the material remaining in the building being unharmed.

\section{Alcohol and Vitamin A}

IN a recent issue of Science it is claimed by Drs. Samuel W. Clausen, Burtis B. Breeze, William S. Baum, Augusta B. MeCoord and John O. Rydeen, of the University of Rochester School of Medicine and Dentistry, that taking alcohol raises the vitamin A content of the blood in men as well as dogs. 'Before-and-after' tests were made on ten persons taking alcohol in the form of mixed drinks as desired. In every case the amount of vitamin A in the blood was increased after the drinking. The increase was relatively slight in most cases but was remarkably large in one person who had a high level of vitamin $\mathrm{A}$ in his blood before the drinking. Night-blindness is one of the chief signs of lack of this vitamin, although it is required for health of other parts of the body besides the eyes, and for normal growth of children.

Tests of ability to see in the dark, one method of determining whether a person is getting enough vitamin A, made after drinking, showed unaccountably short recovery time in dark adaptation. Dr. L. B. Pett, of the University of Alberta, who made this observation, suggested that the reason was the mobilization of vitamin A from its storage place in the body, presumably the liver, to the blood, which would distribute it to other parts of the body including the eyes. The vitamin A tests reported by the Rochester scientific workers were made on the blood, not the eyes. They also believe that the increase in blood vitamin $\mathrm{A}$ after alcohol is due to a mobilization of the vitamin from other tissues. They suggest that this might form the basis of a test for vitamin A storage in the body. 